\title{
Investigation of the incidence rate and geographical distribution of congenital hypothyroidism in the newborns in Ilam Province by using geographic information system (GIS) between 2006 and 2016
}

\author{
Daliri $\mathbf{S}^{1}$, $\underline{\text { ssadollahi }}^{2}$, Karimi A ${ }^{1}$, Ehsanzadeh $A^{3}$, Rezaei $\mathbf{N}^{4}$ \\ 1. Master in Epidemiology, Student Research Committee, Ilam University of Medical Sciences, Ilam, Iran. \\ 2. Professor in Clinical Epidemiology, Faculty of Medicine, Ilam University of Medical Sciences, Ilam, Iran, (Corresponding \\ Author) Tel: +98-84-3222712, Email: masoud_1241@yahoo.co.UK \\ 3. Medical Doctor, Non-Communicable Diseases Deputy of Health, Ilam University of Medical Sciences, Ilam, Iran. \\ 4. Department of Midwifery, Faculty of Nursing and Midwifery, Ilam University of Medical sciences, Ilam, Iran.
}

\begin{abstract}
Background and Aim: Congenital hypothyroidism is an endocrine disorder and is one of the main causes of mental retardation in the newborns. Genetic, environmental and geographical factors are associated with the disease. This study aimed to evaluate the incidence rate and correlation of geographical factors with congenital hypothyroidism in Ilam Province.

Materials and Methods: This study was a descriptive analytical study and evaluated the incidence rate and geographical distribution of congenital hypothyroidism in the newborns in Ilam Province from the beginning of 2006 to the end of 2016. We studied the results of heel samples of the newborns between 3 to 5 days of age who had been screened for congenital hypothyroidism in the referral laboratories of the health centers of the health department of the Ilam University of Medical Sciences in all cities of Ilam Province. We used ArcGIS (ver 10.3) software for evaluation of geographical distribution. Statistical tests of Poisson regression and scatter plot were used to investigate the relationship between geographical factors and the incidence rate of congenital hypothyroidism. Data analysis was performed by use of SPSS 16 software.

Results: Based on the findings of the screening of 106900 newborns born in Ilam Province, the incidence of congenital hypothyroidism in this study was 2.61 in 1000 live births (2.7 male newborns / 1000 live births, and 2.48 female newborns / 1000 live births). Among all the patients 55.4\% were male and $44.6 \%$ were female. There was a significant correlation between the mean annual rainfall and herbal coverage with congenital hypothyroidism $(\mathrm{p}<0.05)$. Mean annual temperature, sunlight and relative humidity had no significant relationship with the disease ( $\mathrm{p}>0.05)$.

Conclusion: Based on the findings of this study, incidence of congenital hypothyroidism is high in Ilam Province. Abdanan and Ilam cities had the highest incidence rates of hypothyroidism and are among the high risk hotspots of the disease. As a result, authorities should take appropriate measures in order to control and reduce the incidence of this disease in the province. Also, among the geographical factors, the mean annual rainfall, herbal coverage and sunlight were associated with congenital hypothyroidism.
\end{abstract}

Key words: Incidence, Geographical distribution, Congenital hypothyroidism, Newborn

Recevied: Jul 8, 2018

Accepted: Feb 20, 2019

How to cite the article: Daliri S, Asadollahi K, Karimi A, Ehsanzadeh A, Rezaei N. Investigation of the
incidence rate and geographical distribution of congenital hypothyroidism in the newborns in Ilam Province
by using geographic information system (GIS) between 2006 and 2016. SJKU 2019; 24 (1): 98-111.

Copyright (C) 2019 the Author (s). Published by Kurdistan University of Medical Sciences. This is an open access article distributed under the terms of the Creative Commons Attribution-Non Commercial License 4.0 (CCBY-NC), where it is permissible to download, share, remix, transform, and buildup the work provided it is properly cited. The work cannot be used commercially without permission from the journal. 


\section{بررسى ميزان بروز و يراكندكى جغر افيايى كمكارى مادرزادى تيروئيد در نوزادان استان ايلام

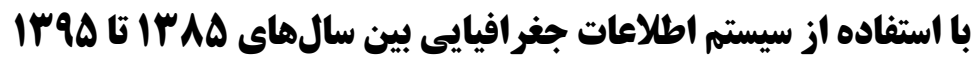

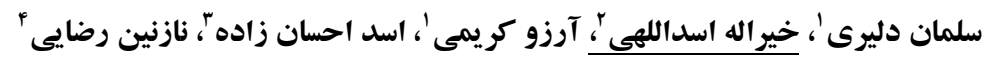

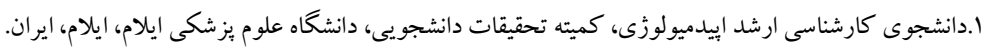

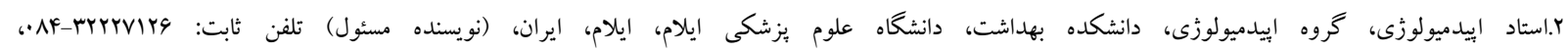
masoud1241@yahoo.co.uk

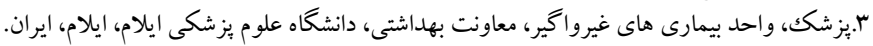

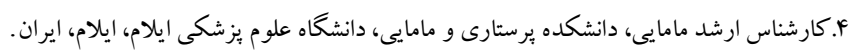

جكيله زمينه و هدف: كم كارى مادرزادى تيروئيد يكك بيمارى اندوكرين بوده و از علل اصلى عقب ماندگى ذهنى در نوزادان به شمار مى

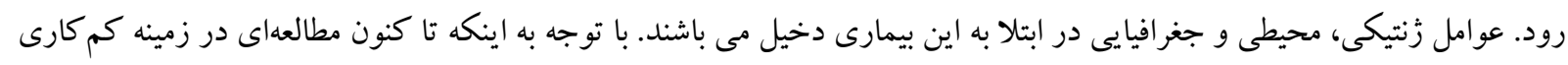

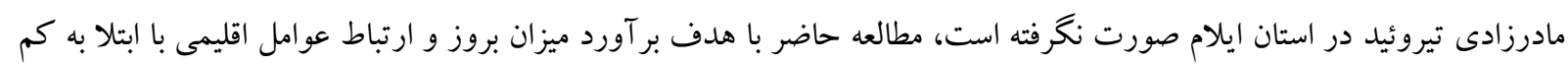
كارى مادرزادى تيروئيد در استان انجام شد.

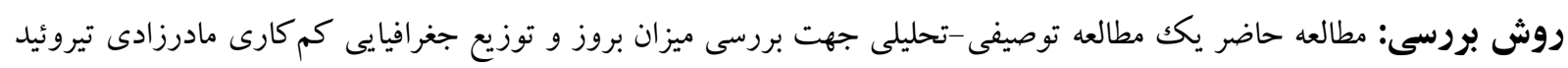

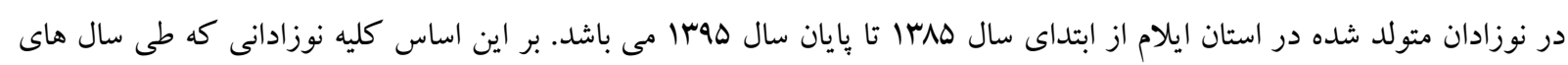

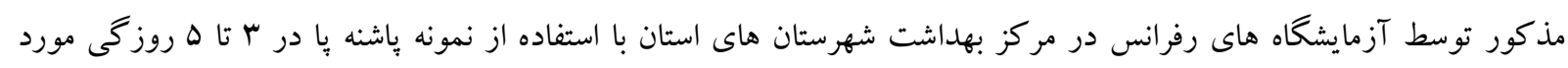

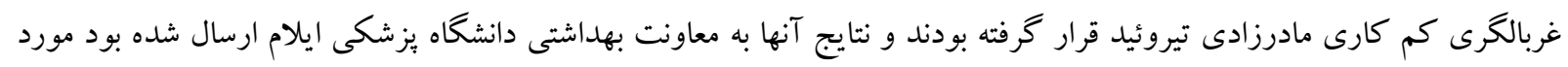

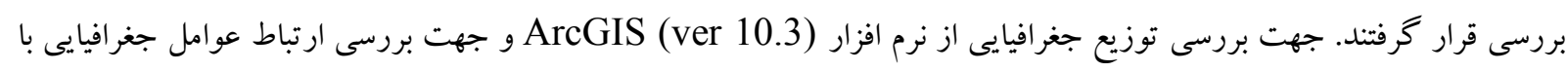

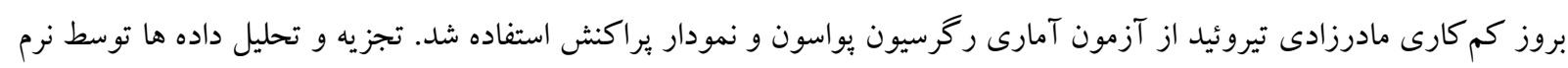

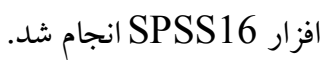

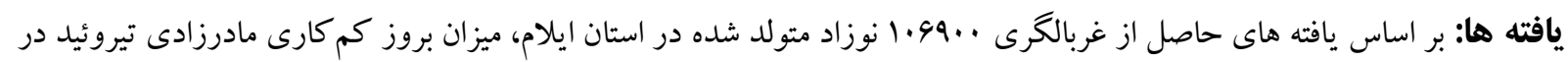

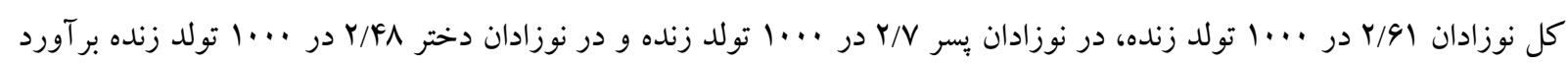

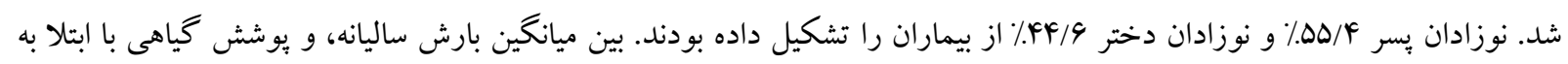

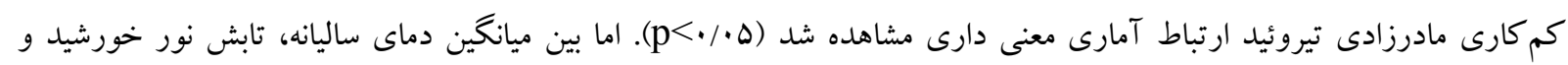

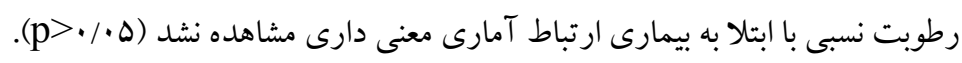

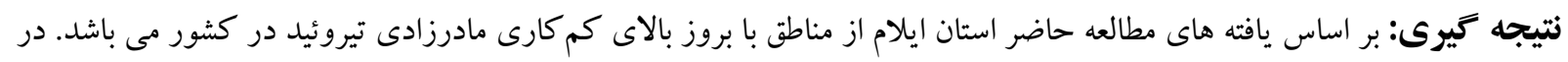

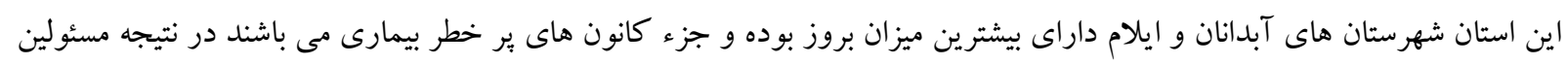

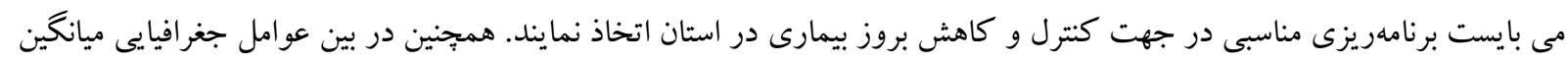

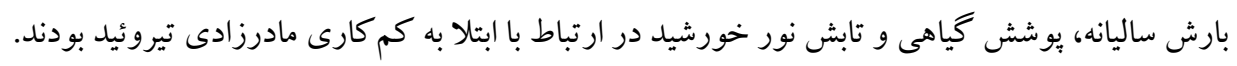

$$
\begin{aligned}
& \text { كليد وازه ها: بروز، براكندگى جغرافيايى، كم كارى مادرزادى تيروئيد، نوزادان } \\
& \text { وصول مقاله:QV/D//V اصلاحيه نهايى:QV/ }
\end{aligned}
$$




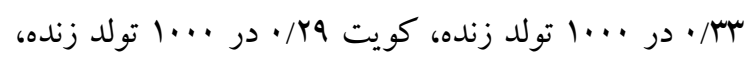

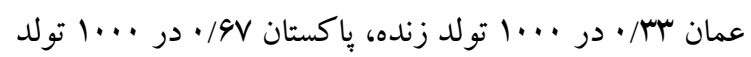

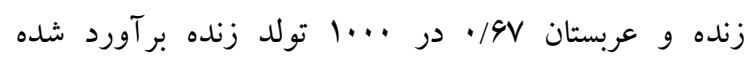
است(Y) (Y). در ايران ميزان بروز كم كارى مادرزادى تيروئيد

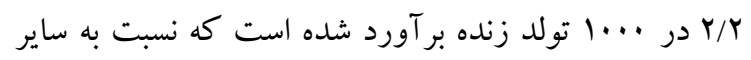

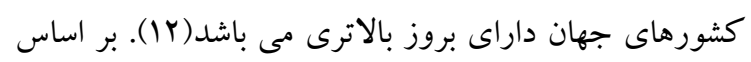

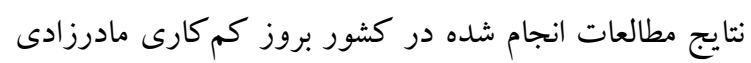

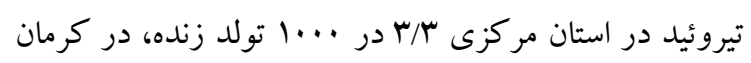

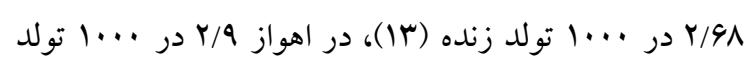

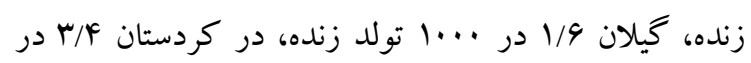

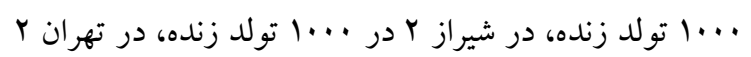

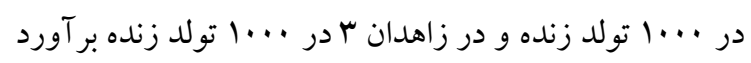

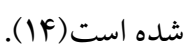
عوامل مختلفى در ارتباط با ابتلا به كم كارى مادرزادى تيروئيد

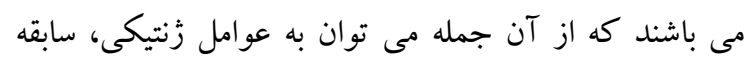

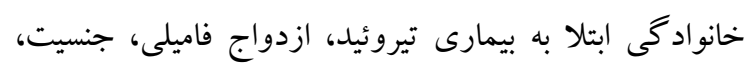

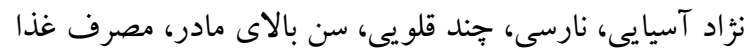

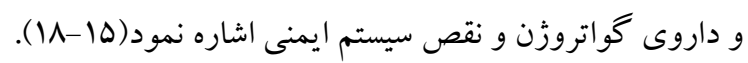

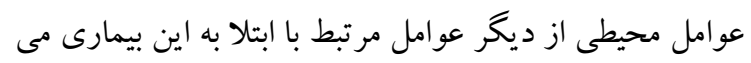
باشد. در جهان مطالعات گوناگونى به بررسى ارتباط تغييرات آنسات

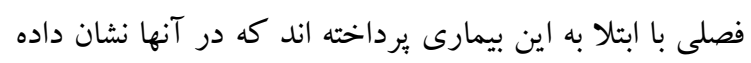

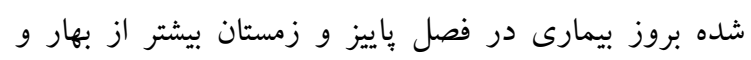

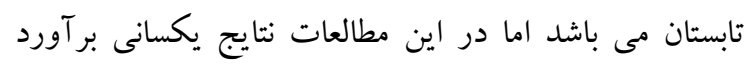

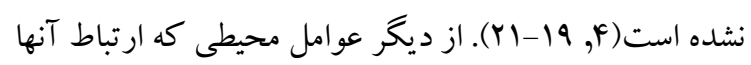

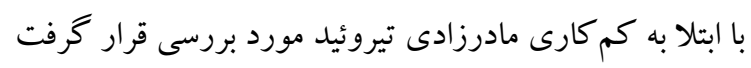
مى توان به ميانگين دماى ساليانه، رطوبت نسبى و ميانگين مادين

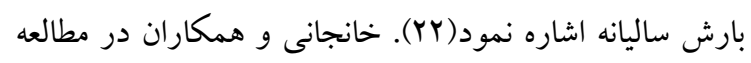

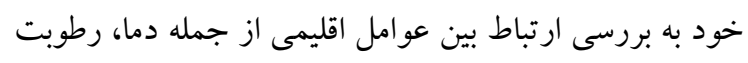
نسبى و ميزان بارش با ابتلا به كم كارى مادرزادى تيروئيد

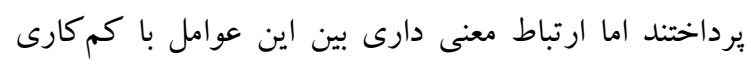

\section{مقدمه}

كم كارى مادرزادى تيروئيد يكى از شايعترين بيمارى هاى

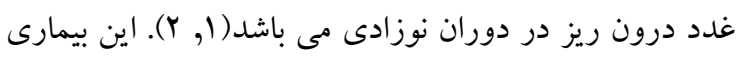

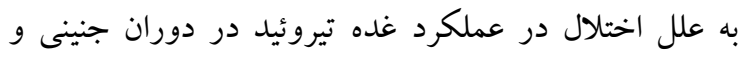

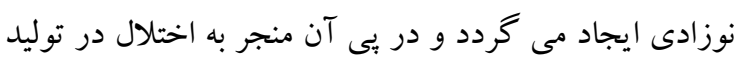

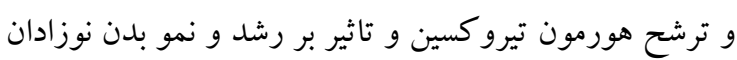

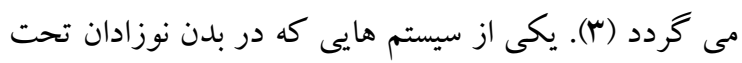

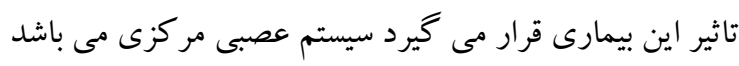

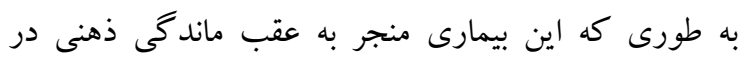

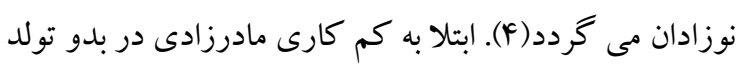

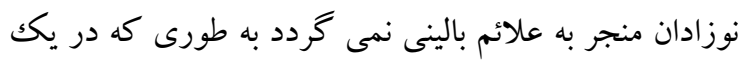

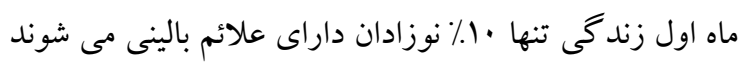

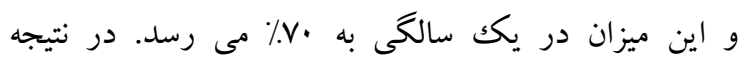

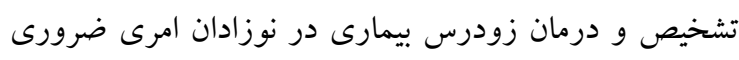

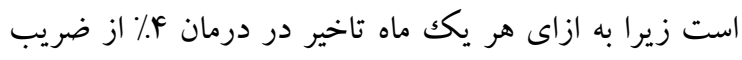

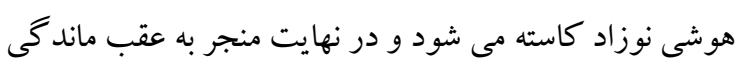

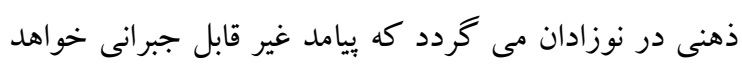
داشت(ه). در دهه كذشته اكثر كشورهاى جهان نسبت به به به

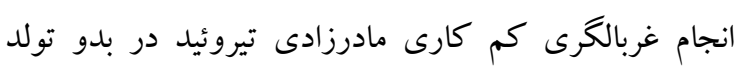

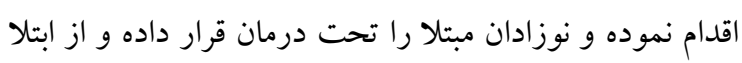
به عقب ماندگى ذهنى بيشخيرى نموده اند(و, V). اين بيمارى

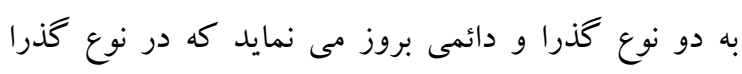

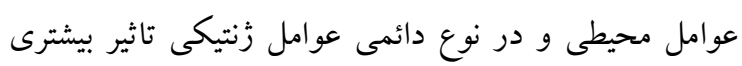

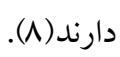

بروز كم كارى مادرزادى تيروئيد در مناطق مختلف جهان

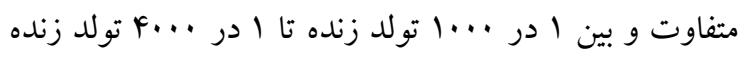
مى باشد (q, · (1). اين ميزان در كشورهاى توسعه يافته از جمله

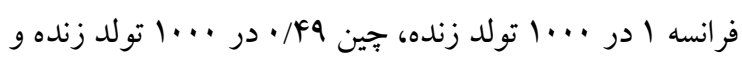

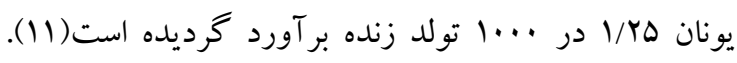
همجنين اين ميزان در كشورهاى در حال توسعه از جمله تركيه 
فيراله اسداللهى 1.1

بهبودتاثير عوامل محيطى از جمله كنترل مصرف يد توسط خانوار ها و كاهش بروز بيمارى انجام شد(YI). بر اين اساس تهر

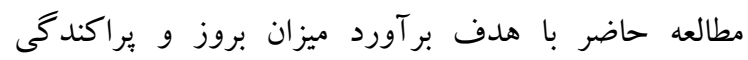
جغرافيايى كم كارى مادرزادى تيروئيد در استان ايلام انجام شد تا بتوان با سبب شناسى و تعيين مناطق يرخطر بيمارى اقدامات بهداشتى و مديريتى مناسبى در جهت كنترل و يشيخيرى از بروز بيمارى اتخاذ نمود.

\section{روش بروسى}

مطالعه حاضر به صورت توصيفى تحليلى بر روى كليه نوزادان غربالكرى شده در بدو تولد در استان ايلام بين سال هاى هیرا تا هوبا انجام شد. حجم نمونه مورد مطالعه به صورت سرشمارى كليه نوزادان متولد شده طى سال هاى مذكور در استان ايلام كه درب تا ه روزگى توسط آزمايشگاه هاى رفرانس در مركز بهداشت شهرستان هاى استان و همجينين معاونت بهداشتى دانشخاه علوم يزشكى ايلام مورد غربالكرى كم كارى تيروئيد قرار گرفته بودند بر آورد شد. بر اين اساس در استان ايلام تعداد . .1. نوزاد مورد غربالخرى قرار

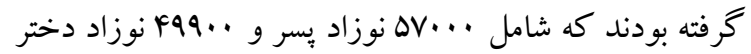
بودند. جهت غربالكرى نوزادان از كيت تجارى كيميا يزوهان (ساخت ايران) استفاده شده بود. جهت انجام اين تست، يكك

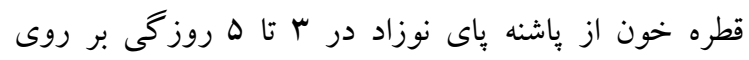

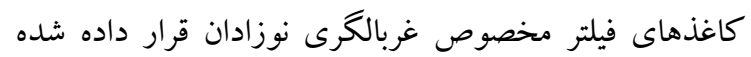
بود و سبس به آزمايشگاه هاى رفرانس مورد تاييد معاونت

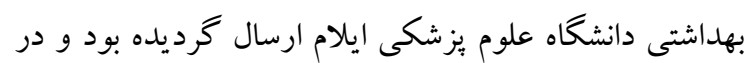

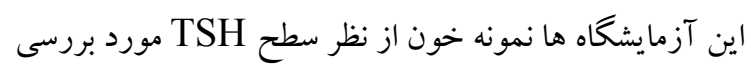
و نتايج به مراكز بهداشتى و معاونت بهداشتى استان اعلام

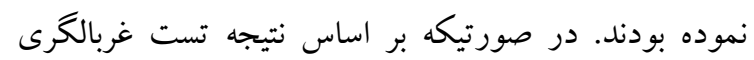

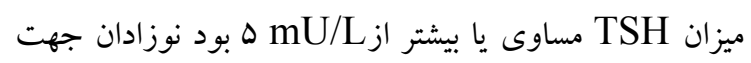

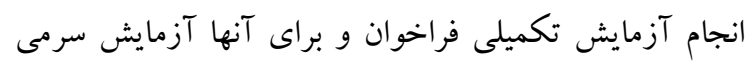
انجام شده بود. در صورتيكه در آزمايش سرمى ميزان TSH
مادرزادى تيروئيد مشاهده نشد(س|). در مطالعه مهرنجات و همكاران ارتباط ميزان نيترات آب آشاميدنى به ابتلا به كمكارى مادرزادى تيروئيد مورد بررسى قرار گرفت كه يافته ها بين ميزان نيترات آب با ابتلا به كم كارى مادرزادى تيروئيد ارتباط آمارى معنى دارى را نشان دادند(r/Y). اصولى و همكارن بروز كم كارى مادرزادى تيروئيد در استان هاى مختلف كشور را مورد ارزيابى قرار دادند كه در اين مطالعه بروز بيمارى در استان هاى مختلف كشور اختلاف معنى دارى داشتند. با توجه به گوناگونى اقليمى در استان هاى كشور مى دئ توان اظهار نمود عوامل اقليمى و محيطى در ابتلا به بيمارى

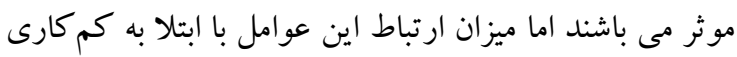
مادرزادى تيروئيد در مطالعات انجام شده به طور دقيق

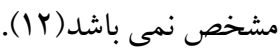

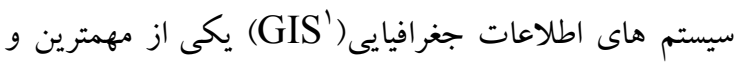
مفيدترين نرم افزارها در بررسى إيدميولوزى، توزيع، انتشار، شناسايى مناطق جغرافيايى و كروه هاى جمعيتى با خطر بالاى إي ابتلا به بيمارى ها مى باشد(YF). در واقع تجمع كروهى بيمارى ها در مكان خاص را مى توان با استفاده از سيستم اطلاعات جغرافيايى بدست آورد و تحليل مكانى بيمارى ها و ارتباط آن با عوامل محيطى رامى توان در محيط GIS با استفاده از قابليت هاى اين سامانه مورد مطالعه و بررسى قرار داد(Y)). در نتيجه تداركى خدمات يِيشيرى، اطلاعات بهداشتى و وايش بيمارى ها در مكان ها و زمان ها از اهميت خاصى برخوردار است(Y9). اكاهى از ميزان بروز و توزيع جغرافيايى و مناطق يرخطر بيمارى ها در سبب شناسى، برنامه ريزى و تصميم گيرى هاى مديريتى و سلامت امرى ضرورى مى باشد. برنامه غربالخرى كم كارى مادرزادى تيروئيد در استان ايلام همزمان با سراسر كشور از ابتداى تير ماه سال IMAF جهت شناسايى و درمان بيماران مبتلا اجراء كرديده است و تلاش هاى فراوانى جهت

1 geographical information system

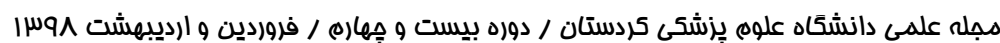


1. بررسى ميزان بروز و .....

بالاترى نسبت به ميانگين 11 ساله بودند به عنوان كانون هاى يرخطر بيمارى در نظر كرفته شدند. معيار هاى ورود به مطالعه شامل كليه نوزادان زنده متولد شده كه مورد غربالخرى كم كارى مادرزادى تيروئيد قرار گرفته بودند، ساكن استان ايلام بودند، آزمايشات سرمى جهت تشخيص قطعى بيمارى انجام داده بودند و نوزادانى كه فاقد معيارهاى ورود بودند از مطالعه خارج شدند. جهت بر آورد ميزان بروز تعداد نوزادان تشخيص داده شده به كم كارى مادرزادى تيروئيد نسبت به كل نوزادان غربالكرى شده با ضريب در .... تولد زنده در نظر گرفته شد. به منظور مدل سازى عوامل مرتبط با ابتلا به كم كارى مادر زادى تيروئيد با توجه به خاصيت شمارشى آن، از آزمون ركرسيون يو اسون استفاده شد. در اين مدل تعداد بيماران به صورت · ل1•، ·متغير وابسته و اطلاعات عوامل جغرافيايى به صورت طبقه

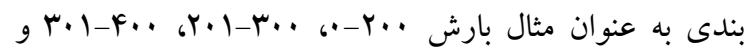

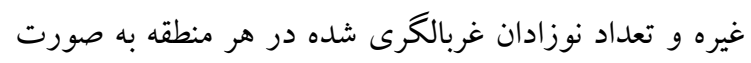
عددى به عنوان متغير مستقل در نظر كرفته شد. همجنين جهت بررسى ارتباط عوامل جغرافيايى با ابتلا به بيمارى از نمودار ير اكنش استفاده شد. رگرسيون يواسون شكلى از تجزيه وتحليل رگرسيونى است كه براى مدل سازى دادهاى شمارشى با فراوانى كم كاربرد دارد. در اين مدل متغير وابسته تعداد وقايع كه متغير عددى غير منفى با توزيع يواسون مى باشد. از معيارهاى استفاده از اين مدل شمارشى بودن دادها، مستقل بودن داده ها و برابر بودن

$$
\text { ميانكين با واريانس مى باشد. }
$$

جهت تجزيه و تحليل آمارى داده ها از نرم افزار SPSS16 و بارسي به منظور تهيه نقشه هاى جغرافيايى از نرم افزار Arc GIS.ver10.3 استفاده شد. سطح معنى دارى هـ • • در نظر

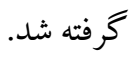

مساوى يا بيشتر از mU/L · ا و T4 كمتر از 9/0 mg/dl بود نوزاد به عنوان بيمار در نظر كرفته شده بودند و مورد درمان

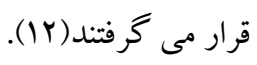

جمع آورى داده ها با استفاده از جکك ليست محقق ساخته كه شامل نتيجه غربالكرى، آدرس محل سكونت، جنسيت نوزاد و سال تولد نوزاد بود انجام شد. بر اين اساس با مراجعه به

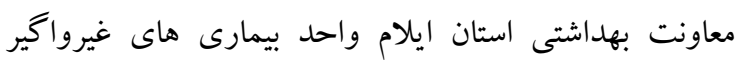
اطلاعات مورد نياز كليه نوزادان متولد شده ساكن استان ايلام كه توسط آزمايشخاههاى رفرانس مورد غربالخرى قرار كرفته بودند استخراج و وارد جّك ليست مذكور شد. جهت نقشه سازى مناطق جغرافيايى از جمله نقشه استان ايلام به تفكيك

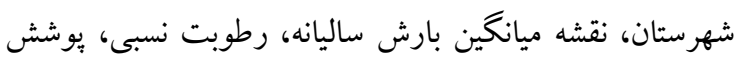

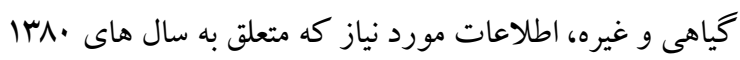
تا هوس ا بود از سازمان هاى مسكن و شهرسازى و منابع طبيعى و آبخيز دارى دريافت و با استفاده از نرم افزار ArcGIS.ver10.3 نقشه ها تهيه گرديد. اين نرم افزار در شناسايى، توزيع و بررسى الكوى جغر افيايى و زمانى بيمارى ها مفيد بوده كه يس از تهيه اطلاعات مورد نياز در زمينه منطقه جغرافيايى مورد بررسى و هميجنين وقوع بيمارى ها در آن منطقه با اضافه نمودن اطلاعات مربوطه به اين نرم افزار مى لى لرئ توان نسبت به تهيه نقشه ها و بروز بيمارى ها در اين مناطق به صورت تصوير دست يافت(YY, YV (YV). جهت ترسيم نقشه هاى GIS

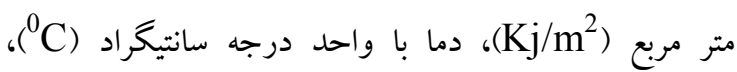
رطوبت نسبى واحد درصد و بارش هم بر اساس ميلى متر در سال جمع آورى شد، سيس اين داده ها وارد نرم افزار اكسل كرديده و به نرم افزار Arc GIS.ver10.3 اضافه كرديد. بروز بيمارى به صورت تعداد موارد در ...1 تولد زنده محاسبه و جهت تعيين كانون هاى برخطر بيمارى ميانگين ميزان بروز Iا ساله استان محاسبه و مناطقى كه داراى بروز 
بود. همجنين از بrV نوز اد مبتلا كه ب سال از تولد آنها كذشته

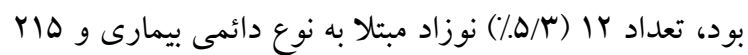
نوزاد به نوع گذرا مبتلا بودند. بررسى روند |ل ساله بروز كم كارى مادرزادى تيروئيد نشان داد بيشترين ميزان بروز به سال |وسا و كمترين ميزان بروز به سال هوسا تعلق داشت. به طور

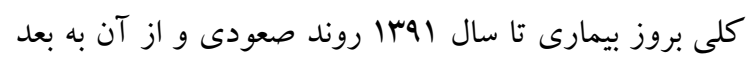
روند نزولى داشته است (نمودار ().
غربالكرى . .99.1 نوزاد متولد شده در استان ايلام بين سال

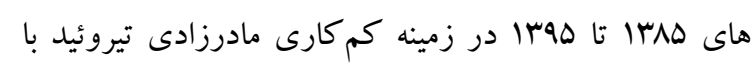
استفاده از نمونه خون بِشنه باى نوزاد و آزمايش سرمى TSH

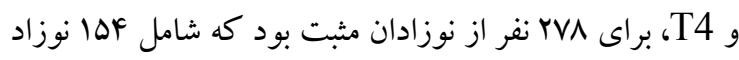

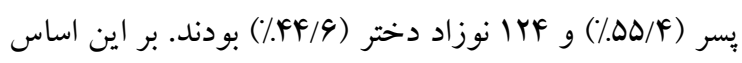
ميانگين ميزان بروز Iل 11 ساله كم كارى مادرزادى تيروئيد در كل نوزادان متولد شده استان ايلام كه مورد غربالكرى قرار

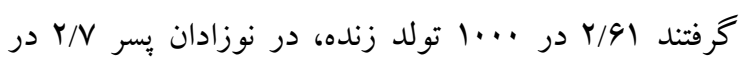

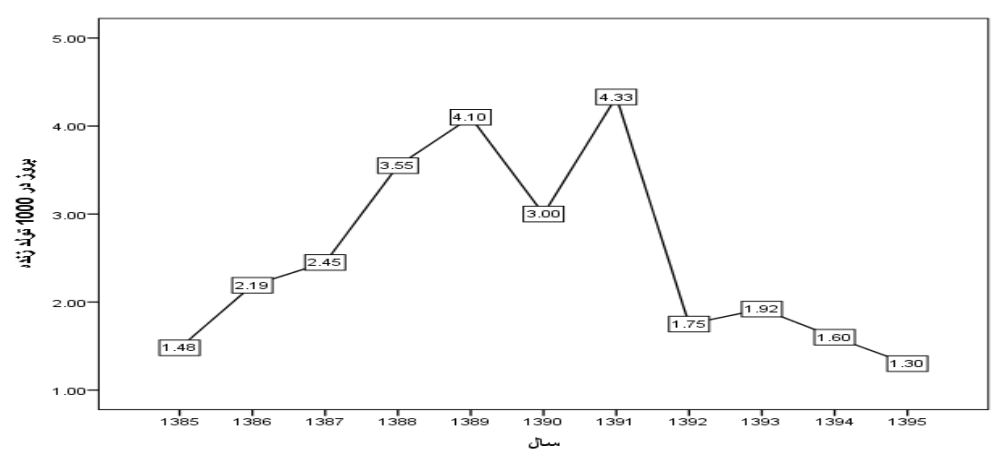

نمودار ا. روند بروز ابتلا به كم كارى مادرزادى تيروئيد در استان ايلام بين سال هاى هیr| تا هوسا
بررسى ميزان بروز ابتلا به كم كارى مادرزادى تيروئيد به تفكيك جنسيت و شهرستان نشان داد، بيشترين ميزان بروز بيمارى در نوزادان يسر به شهرستان آبدانان و كمترين ميزان بروز به شهرستان مهران و در نوزادان دختر بيشترين ميزان بروز بيمارى به شهرستان آبدانان و كمترين ميزان بروز به شهرستان دهلر ان تعلق داشت(نقشه ب و r). بر اساس يافتها بيشترين ميزان بروز كم كارى مادرزادى

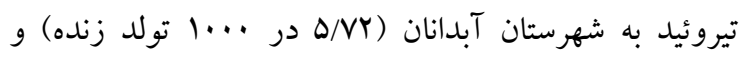

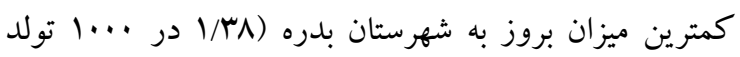

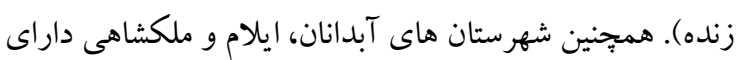
ميزان بروز بيشتر از ميانخين 11 ساله استان بوده و به عنوان كانون هاى يرخطر بيمارى در نظر گرفته شدند (نقشه (1). 


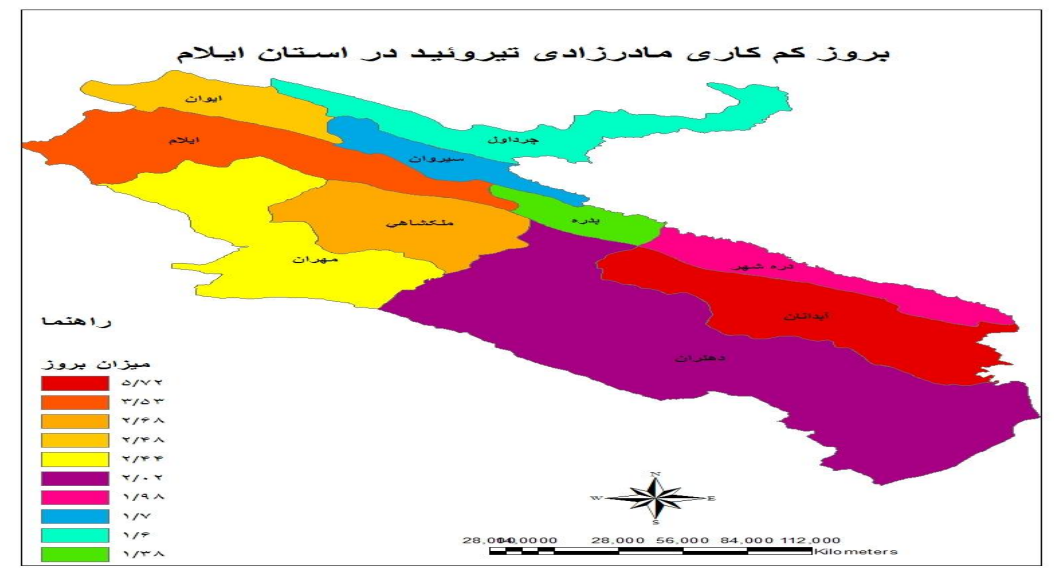

نقشه ا-ميانخين ميزان بروز 11 ساله كم كارى مادرزادى تيروئيد در كل نوزادان به تفكيك شهرستان در استان ايلام

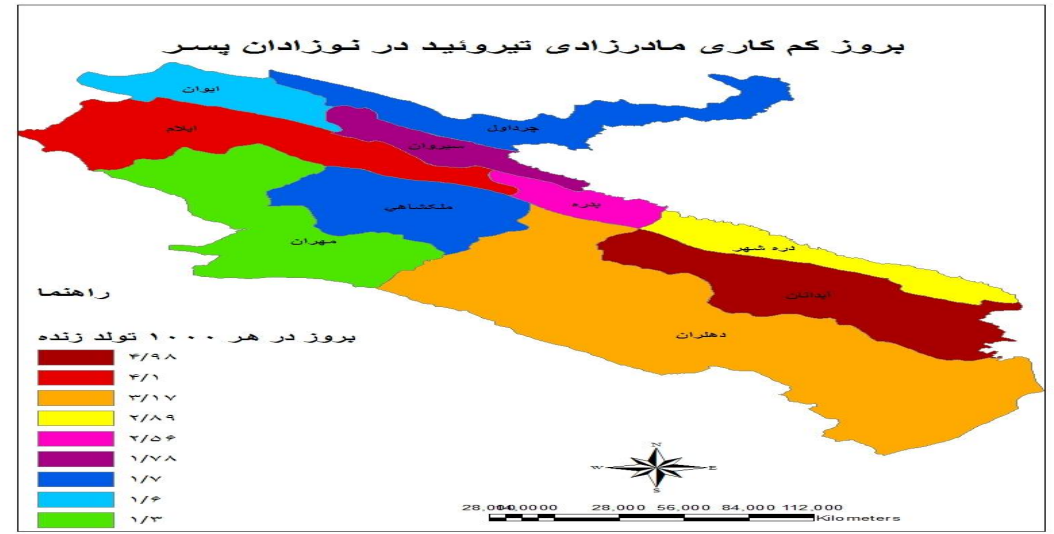

نقشه Y- ميانگين ميزان بروز 11 ساله كم كارى مادرزادى تيروئيد در نوزادان پِر به تفكيك شهرستان در استان ايلام

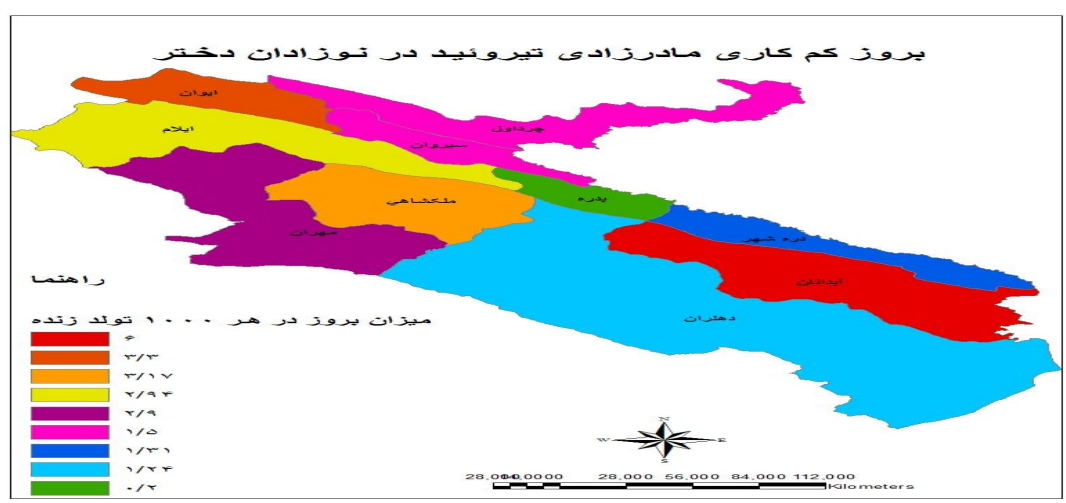

نقشه بـ- ميانگين ميزان بروز ل1/ ساله كم كارى مادرزادى تيروئيد در نوزادان دختر به تفكيك شهرستان در استان ايلام

بروز بيمارى افزايش مىيافت به طورى كه بيشترين ميزان بروز مربوط به مناطق با تابش

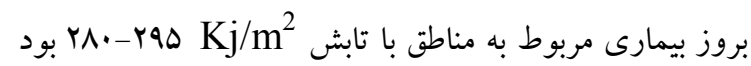

يافته هاى حاصل از بررسى ارتباط ابتلا به كم كارى مادرزادى تيروئيد در استان ايلام با ميزان تابش نور خورشيد با استفاده از بـان نمودار پيراكنش نشان داد با افزايش ميزان تابش نور خورشيد

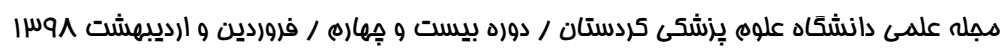


فيراله اسداللهى 1.00

(نمودار r) اما با استفاده از آزمون ركرسيون يواسون ارتباط مربوط به ميانگين دماى

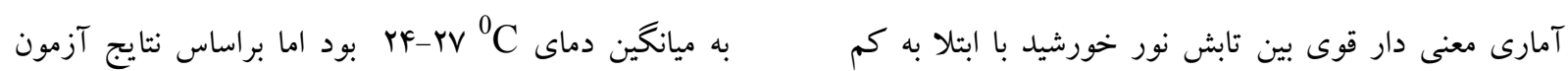

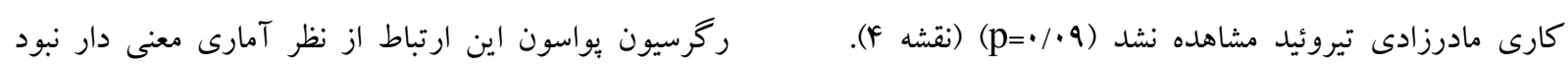

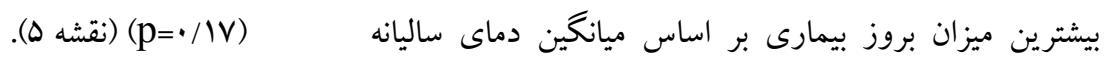

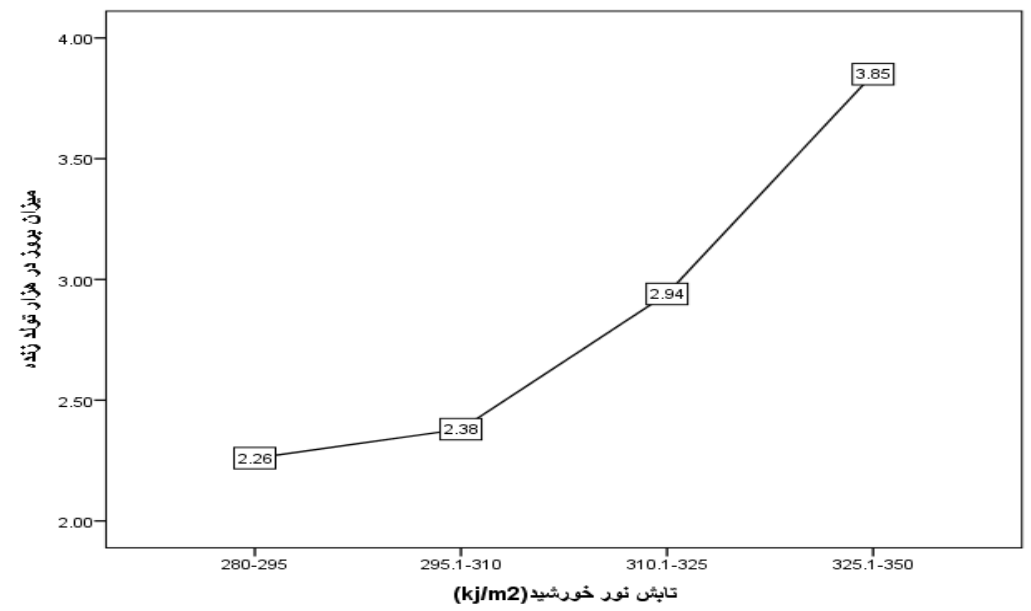

نمودار r- ارتباط ميزان بروز كم كارى مادرزادى تيروئيد با ميانگين تابش نور خورشيد

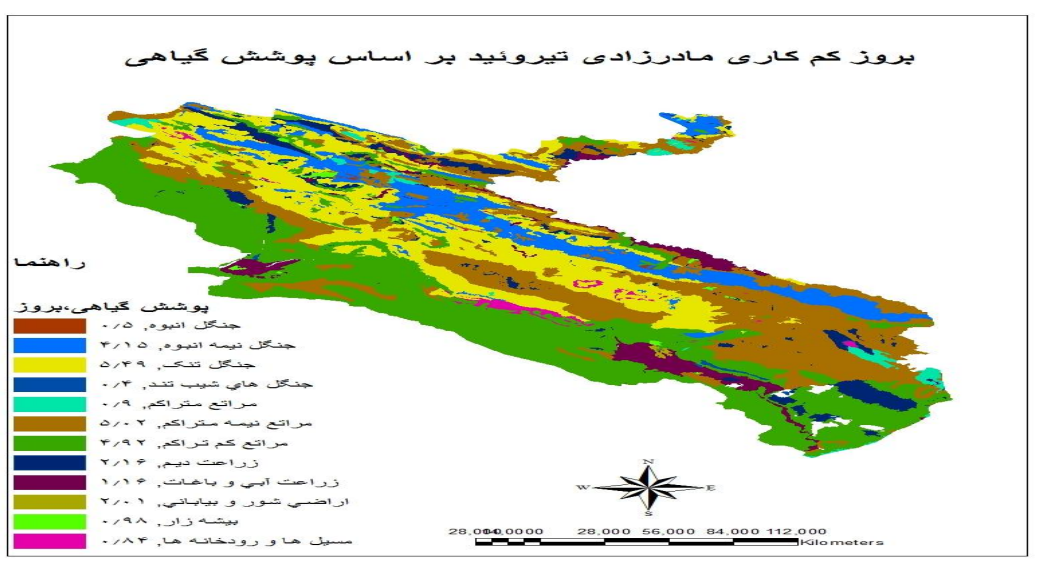

نقشه F- ميانكين ميزان بروز لا ساله كم كارى مادرزادى تيروئيد بر اساس ميزان تابش نور خورشيد در استان ايلام 


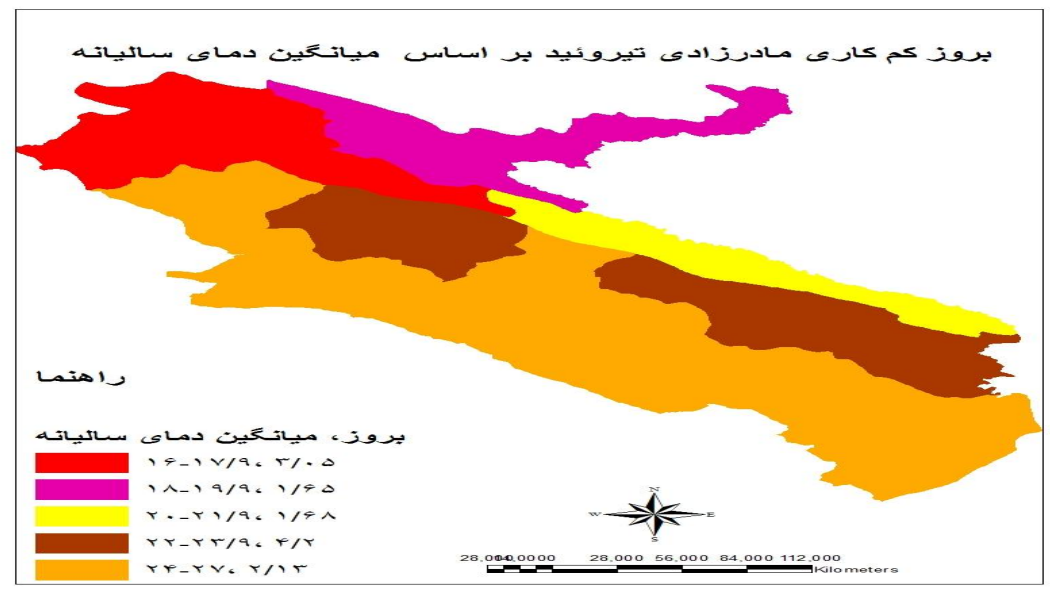

نقشه ه- ميانكين ميزان بروز 11 ساله كم كارى مادرزادى تيروئيد بر اساس ميانگين دماى ساليانه در استان ايلام

افزايش تا ميانكين بارش .9. - ... ميلى متر ادامه داشت و

يس از آن اين اختلاف معنى دار نبود. به طور كلى كمترين

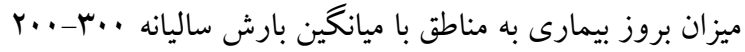

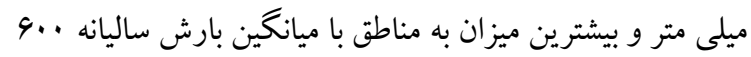
- - .. ه تعلق داشت كه اين ارتباط از نظر آمارى معنى دار بود

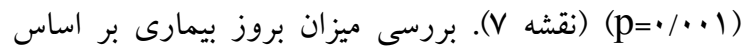
رطوبت نسبى نشان داد، بيشترين ميزان بروز بيمارى به مناطق با

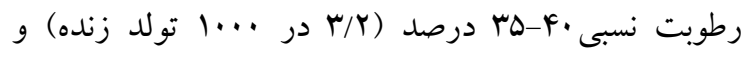
كمترين آن به مناطق با رطوبت نسبى •ه-ها درصد (1/91/ در

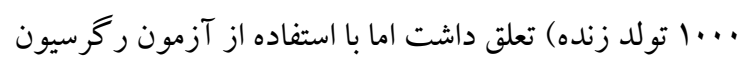
يو اسون اين رابطه آمارى معنى دار نبود(س (P=//) (نقشه A).
بررسى ميزان بروز ابتلا به كم كارى مادرزادى تيروئيد بر اساس بوشش گياهى در استان ايلام نشان داد مناطقى كه برونى داراى بوشش گياهى بيشترى بودند بروز بيمارى كمتر و بالعكس در مناطق با يوشش گياهى ضعيف بروز بيمارى افزايش مى يافت به طورى كه كمترين ميزان بروز بيمارى به جنگل هاى انبوه، جنگل هاى شيب تند و مراتع متراكم و بيشترين ميزان بروز بيمارى به جنگل هاى تنك، مراتع نيمه متراكم و مراتع كم تراكم تعلق داشت كه براساس نتايج آزمون رگرسيون يواسون اين اختلاف ميزان بروز از نظر

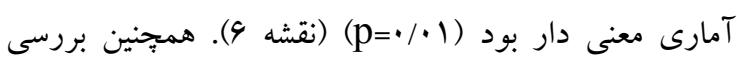

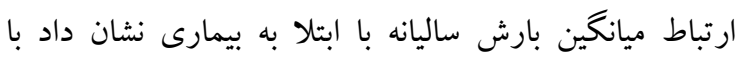

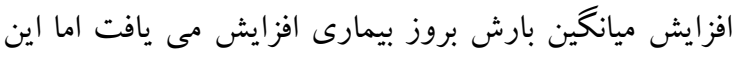

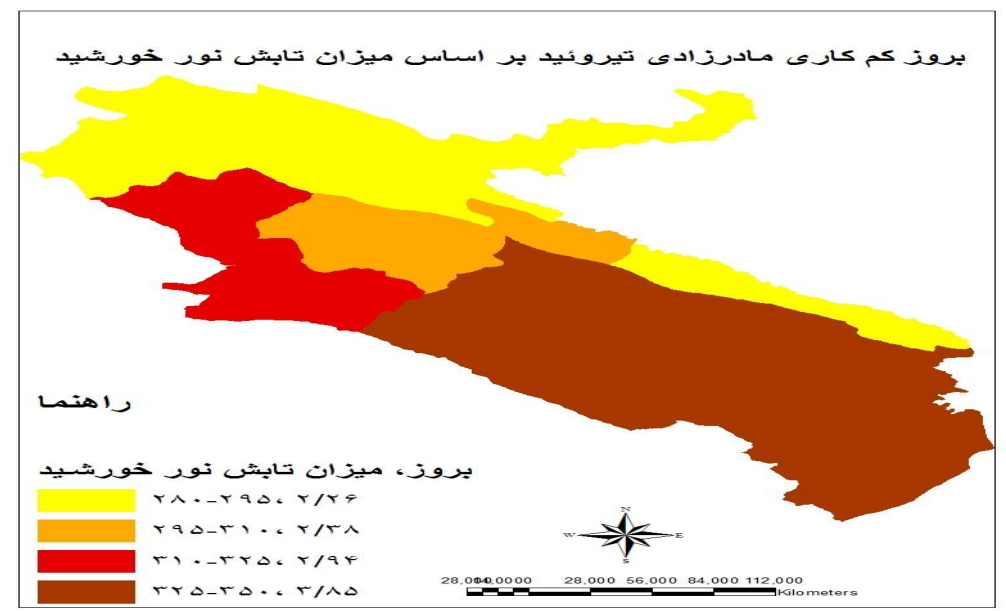

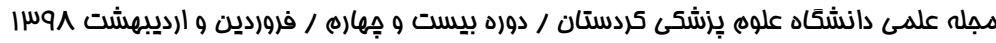


نقشه 9- ميانگين ميزان بروز 11 ساله كم كارى مادرزادى تيروئيد بر اساس يوشش گياهى در استان ايلام

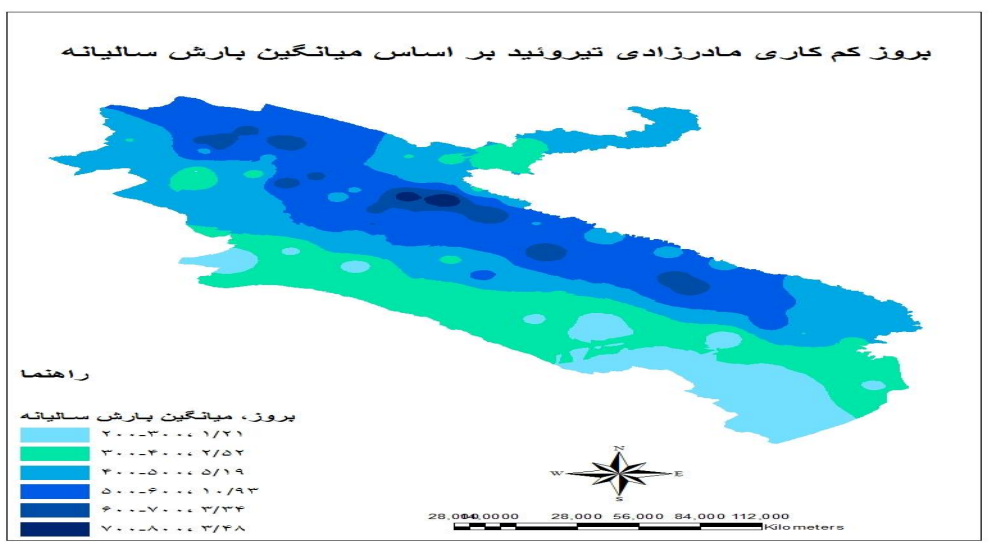

نقشه V- ميانخين ميزان بروز 1 اساله كم كارى مادرزادى تيروئيد بر اساس ميانگين بارش ساليانه در استان ايلام

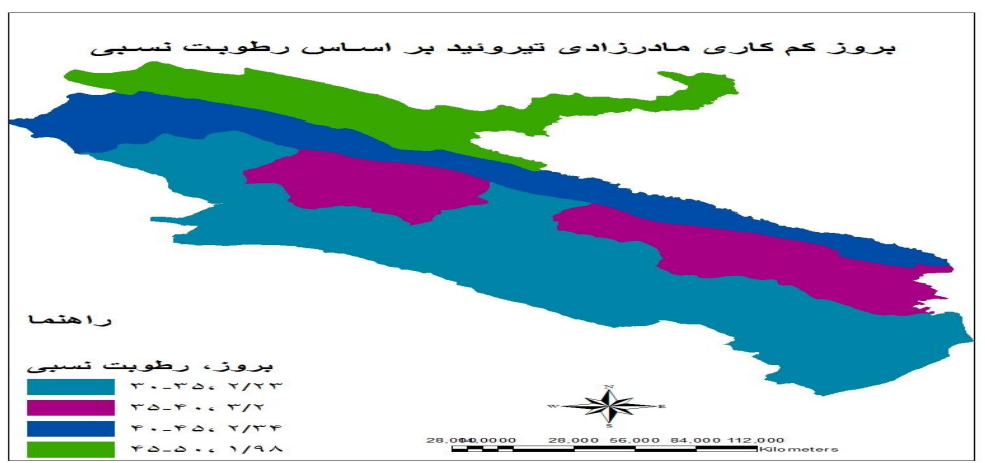

نقشه ^- ميانگين ميزان بروز 11 ساله كم كارى مادرزادى تيروئيد بر اساس رطوبت نسبى در استان ايلام

كارى مادرزادى تيروئيد در كل نوزادان ^/1 در ..... تولد

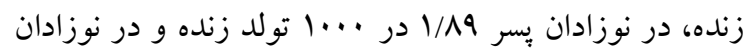

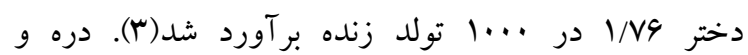

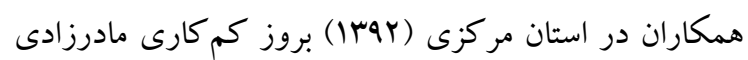
تيروئيد س/ در ... . تولد زنده بر آورد نمودند(F). صيامى و همكاران (سوسו) در مازندران بروز كم كارى مادرزادى

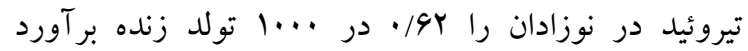
نمودند(YN). در مطالعه بهشتى و همكاران در شمال ايران (IrqV) 1....

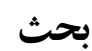

مطالعه حاضر به صورت توصيفى تحليلى جهت بررسى ميزان بروز و توزيع جغرافيايى كم كارى مادرزادى تيروئيد در استان ايلام انجام شد. بر اين اساس ميانگين ميزان بروز بيمارى در

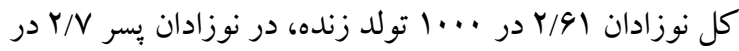
.... بود. در مطالعه انجام شده توسط نيلى و همكاران در كردستان

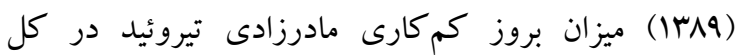

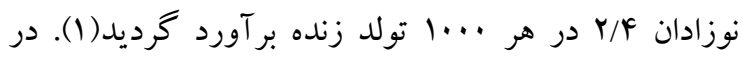
مطالعه نمكين و همكاران در خراسان جنوبى (| (| |) بروز كم 


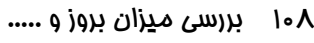

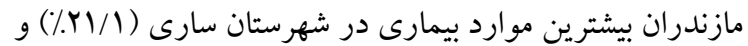
كمترين موارد بيمارى در شهرستان كلو گاه (س/1\%) رخ داده بود(YN)، كه مى توان اظهار نمود به علت اينكه ابتلا به كمكارى مادرزادى تيروئيد در ارتباط با عوامل گوناگونى مى لـى باشد در نتيجه بروز آن حتى در شهرستان هاى يكك استان نيز

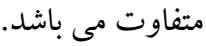
يافته هاى مطالعه حاضر نشان داد كه ارتباط آمارى معنىدارى بين ابتلا به كم كارى مادرزادى تيروئيد با تابش نور خورشيد، ميانگين بارش ساليانه و بوشش گياهى وجود دارد. اما بين

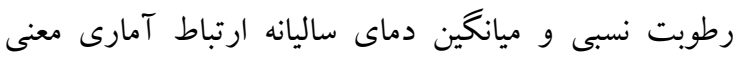
دارى مشاهده نشد. اگرّهه مطالعات زيادى در جهان در زمينه عوامل اقليمى با ابتلا به كم كارى مادرزادى تيروئيد انجام نشده است اما با توجه به اينكه در ابتلا به اين بيمارى يد به به به به بهرئ عنوان يكك عامل محيطى موثر مى باشد در نتيجه نمى توان ارتباط عوامل محيطى با ابتلا به اين بيمارى را انكار كرد( آس).

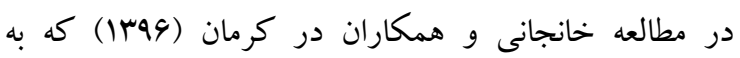
بررسى ارتباط عوامل جغرافيايى با ابتلا به كم كارى مادرزادى تيروئيد يرداخته بودند بين رطوبت نسبى و ميانگين دماى ساليانه با ابتلا به بيمارى ارتباط آمارى معنى دارى مشاهده نشد. اكر جه در برخى از شهر ستانهاى اين استان بين ميانگين بارش ساليانه با ابتلا به كم كارى مادرزادى تيروئيد ارتباط معنى دارى مشاهده شد اما به طور كلى اين رابطه از لحاظ آمارى معنى دار نبود( (1). در مطالعه انجام شده توسط Deng و همكاران

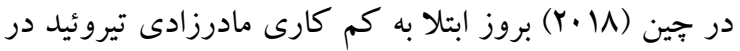
مناطق ساحلى بيشتر از ساير مناطق اين كشور بود(1). در مطالعه اصولى و همكاران (IMAV) كه به بررسى توزيع جغرافيايى كم كارى مادرزادى تيروئيد در ايران برداخته بودند بيشترين بروز بيمارى به استان هاى سيستان و بلوجستان، يزد، جهارمحال بختيارى، ايلام و اروميه و كمترين ميزان بروز بيمارى به استان هاى بندرعباس، لرستان و رشت تعلق داشت(Y) (I). همجنين در مطالعه مهران و همكاران (99 I) كه
ويسانى و همكاران در ايران بروز كم كارى مادرزادى تيروئيد در نوزادان r در ...1 تولد زنده بر آورد شد(·r). بر اساس يافته هاى مطالعه حاضر و ساير مطالعات انجام شده در كشور مى توان بيان نمود استان ايلام از مناطق با بروز بالاى ابتلا به كم كارى مادرزادى تيروئيد مى باشد. با توجه به اينكه طى دهه هاى قبل اقدامات مداخله اي از جمله اضافه نمودن يد به نمكك مصرفى و يد درمانى در دوران باردارى براى مادر انجام مى شود اما هنوز بروز اين بيمارى در استان ايلام بيش از

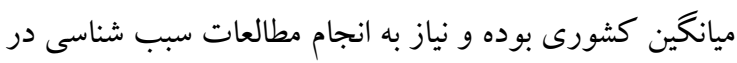
سطح فردى و انجام اقدامات مداخله اى جهت بيشخيرى از بروز كم كارى مادرزادى تيروئيد مى باشد. بررسى وقوع بيمارى براساس جنسيت نشان داد \&ههـ/ از

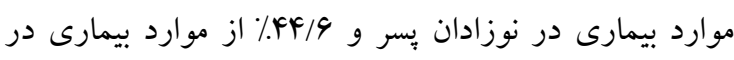

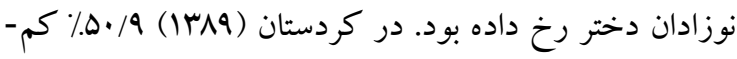

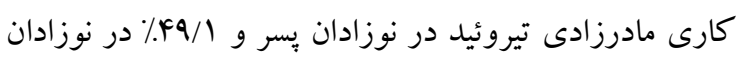

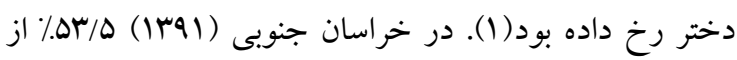
بيماران را جنسيت يسر و \$4/ه٪ را جنسيت دختر تشكيل داده

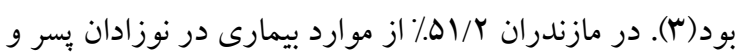

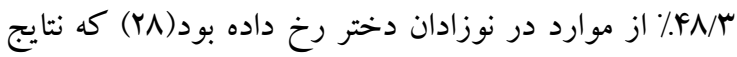
اين تحقيق و تحقيقات مشابه نشان مىدهد بروز بيمارى در نوزادان بسر بيشتر از نوزادان دختر مى باشد. بر اساس يافته هاى حاصل از مطالعه حاضر بيشترين ميزان بروز بيمارى به شهرستانهاى آبدانان و ايلام و كمترين ميزان بروز به شهرستان هاى بدره، سيروان و جرداول تعلق داشت. در مطالعه انجام شده در كردستان بيشترين ميزان بروز كم كارى مادرزادى تيروئيد به شهرستان سقز (ه در .... تولد زنده) و كمترين ميزان بروز به شهرستان بانه (ا در .... تولد زنده) تعلق داشت(1). در خراسان جنوبى بيشترين بروز بيمارى مربوط به شهرستان سرايان (1/ (1/ در ...1 تولد زنده) و

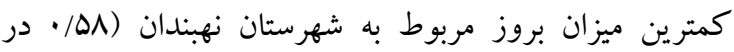
..... 
محدوديت ها

1-عدم مشخص بودن خانواده هاى كه قبلا در استان يا شهرستان هاى ديخر سكونت داشتند و در هنگام تولد نوزاد به اين استان يا ساير شهرستان هاى استان ايلام مهاجرت نموده اند. Y- عدم مشخص بودن نزاد نوزاد كه مى تواند بر ابتلاى آن به بيمارى موثر باشد. r- عدم مشخص بودن وضعيت نوزاد در بدو تولد از جمله تولد زودرس، كم وزنى بدو تولد، بسترى در بيمارستان و تعويض خون كه مى تواند بر نتيجه غربالكرى تاثير بخذارد.

\section{نتيجه Fيرى}

بر اساس يافته هاى مطالعه حاضر استان ايلام از مناطق با بروز بالاى كم كارى مادرزادى تيروئيد در كشور مى باشد. در اين استان شهرستان هاى آبدانان و ايلام داراى بيشترين ميزان بروز بوده و جزء كانون هاى ير خطر بيمارى مى باشند در نتيجه مسئولين مى بايست برنامه ريزى مناسبى در جهت كنترل و كاهش بروز بيمارى در استان اتخاذ نمايند. همجنين در بين

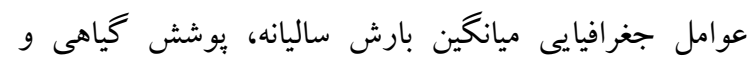
تابش نور خورشيد در ارتباط با ابتلا به كم كارى مادرزادى تيروئيد بودند.

\section{تشكر و قدردانى}

بدينوسيله از معاونت بهداشتى و معاونت تحقيقات و فناورى

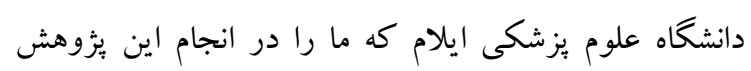

$$
\text { يارى رساندند تشكر و قدردانى مى كردد. }
$$

به بررسى بروز كم كارى مادرزادى تيروئيد در ايران يرداخته بودند بيشترين ميزان بروز بيمارى به استانهاى سيستان و بلوجّتان، يزد، كرمان، ايلام، لرستان، كردستان، خراسان شمالى و جنوبى و كمترين ميزان بروز بيمارى به اردبيل، بابل، كيلان، كلستان، همدان، شاهرود و تربت حيدريه تعلق داشت(f) (I). در مطالعه انجام شده توسط دلشاد و همكاران بيان شد بين ميزان بارش، يوشش گياهى و مجاورت با دريا و

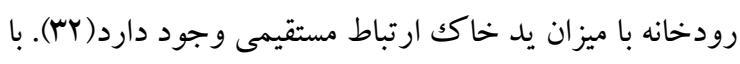
توجه به نتايج مطالعات مذكور مى توان اظهار نمود يكى از علل اينكه استانهاى شمالى كشور داراى بروز كمتر بيمارى مىباشند اين است كه اكرجه اين استانها داراى بارش بيشتر

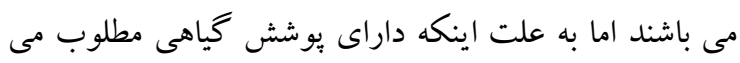
باشند اين بارش موجب فرسايش خاكك و در بيى آن موجب كاهش يد نمى گردد اما استان هاى غربى كشور از جمله لرستان، كردستان، ايلام و خراسان شمالى به علت بوشش كياهى ضعيف، بارش زياد مى تواند موجب فرسايش خاكك و كاهش يد خاكك گردند همجينين استانهاى سيستان و و بلوجستان، يزد و كرمان كه كويرى و فاقد بوشش گياهى بوده داراى بروز بالاى كم كارى مادرزادى تيروئيد مى باشند كه

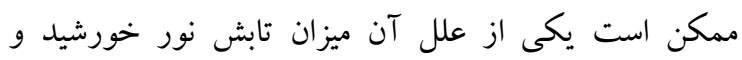
افزايش فرسايش خاكك باشد اكر جه عو امل مختلف ديخرى از جمله نزاد، نوع تغذيه، سابقه خانوادگى و غيره مى تواند در ابتلا به كم كارى مادرزادى تيروئيد موثر باشند كه مشخص نمودن تاثير اين عوامل در ابتلا به كم كارى مادرزادى تيروئيد نياز به انجام مطالعات گستردهتر دارد.

\section{References}

1. Nili S, Ghotbi N. The rate of congenital hypothyroidism in newborns born in Kurdistan province. Quarterly Journal of Monitoring 2010;10:15-20.

2. Eftekhari N, Asadikaram G, Khaksari M, Salari Z, Ebrahimzadeh M. The prevalence rate of congenital hypothyroidism in Kerman/Iran in 2005-2007. JKMU 2008;15:243-50.

3. Namakin K, Sedighi E, Sharifzadeh G, Zardast M. Prevalence of congenital hypothyroidism In South Khorasan province (2006-2010). J Birjand Univ Med Sci 2012;19:191-9. [In Pesian] 
110 براسى ديزان بروز و .....

4. Dorreh F, Chaijan PY, Javaheri J, Eshrati B, Amiri Z. Evaluation of 6 years performance of screening program of congenital hypothyroidism in Markazi province (2006-2012). AMUJ2013;16:40-7. [In Pesian]

5. Rafati M, Ghotbi M, Ahmadnia H. Principles of disease prevention and care and noncommunicable diseases care system. Tehran: White leaf garden book; 2008: 119-28. [In Pesian]

6. Delavari A, Ahmadi SY, Birjandi R, Mahdavi A, Nejad AN, Dini M. Cost-Benefet analysis of the neonatal screening program implamentation for congenital hypothyroidism in I.R. Iran. Int $\mathbf{J}$ Endocrinol Metab 2006;4:84-7.

7. Tuhan H, Abaci A, Cicek G, Anik A, Catli G. Levothyroxine replacement in primary congenital hypothyroidism: the higher the initial dose the higher the rate of overtreatment. J Pediatr Endocrinol Metab 2016;29:133-8.

8. Medda E, Olivieri A, Stazi M, Grandolfo M, Fazzini C, Baserga M. Risk factors for congenital hypothyroidism: results of a population case-control study (1997-2003). Eur J Endocrinol 2005; 153:765-73.

9. Barry Y, Bonaldi C, Goulet V, Coutant R, Leger J. Increased incidence of congenital hypothyroidism in France from 1982 to 2012: a nationwide multicenter analysis. Ann Epidemiol 2016;26:100-5.

10. Mitrovic K, Vukovic R, Milenkovic T, Todorovic S, Radivojcevic J. Changes in the incidence and etiology of congenital hypothyroidism detected during 30 years of a screening program in central Serbia. Eur J Pediatr 2016;175:253-9.

11. Denga K, Hea C, Zhu J, Liang J, Li X, Xie X, et al. Incidence of congenital hypothyroidism in China: data from the national newborn screening program, 2013-2015. J Pediatr Endocrinol Metab 2018;31:601-8.

12. Osooli M, Haghdoost A ,Yarahmadi S, Foruzanfar M, Dini M, Naieni KH. Spatial distribution of congenital hypothyroidism in Iran using geographic information system. IRJE 2009;5:1-8. [In Persian]

13. Khanjani N, Ahmadzadeh A, Bakhtiari B, Madadizadeh F. The role of season and climate in the incidence of congenital hypothyroidism in Kerman province, Southeastern Iran. J Pediatr Endocrinol Metab 2017;30:149-57.

14. Mehran L, Yarahmadi S, Khalili D, Nazeri P, Delshad H, Abdollahi Z, et al. The Impact of Iodine Status on the Recall Rate of the Screening Program for Congenital Hypothyroidism: Findings from Two National Studies in Iran. Nutrients 2017;9:1-10.

15. Huang C, Jap TA. systematic review of genetic studies of thyroid disorders in Taiwan. J Chin Med Assoc 2015;78:145-53.

16. Nicholas A, Serra E, Cangul H, Al-Yaarubi S, Ullah I. Investigating the genetic architecture of gland-in-situ congenital hypothyroidism by comprehensive screening of eight known causative genes. Endocr Abstracts 2015;38:55-9.

17. Rezaeian S, Moghimbeigi A, Esmailnasab N. Gender differences in risk factors of congenital hypothyroidism: an interaction hypothesis examination. Int J Endocrinol Metab 2014;12:139-46.

18. Szinnai G. Clinical genetics of congenital hypothyroidism. Endocr 2014;26:60-78.

19. Miyai K, Inaoka K, Miyagi T. Further studies on episodic occurrence of congenital dysgenetic hypothyroidism in Osaka, Japan. Endocr J 2005;52:599-603.

20. Hashemipour M, Amini M, Kelishadi R, Hovsepian S, Haghighi S. Seasonal variation in the incidence of congenital hypothyroidism in Isfahan, Iran. Saudi Med J 2007;28:1582-6.

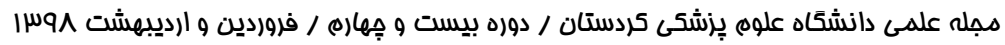


فيراله اسداللهى

21. Ordoukhani A, Mirmiran P, Mehrabi Y, Goldasteh A, Padyab M. Forecasting of recall rate in the screening program for congenital hypothyroidism. IJEM 2003;1:133-8. [In Persian]

22. Aminzadeh M, Chomeili B, Riahi K, Dehdashtian M, Cheraghian B. Effect of temperature changes on the occurrence of congenital hypothyroidism. J Med Screen 2010;17:121-4.

23. Mehrnejat N, Yazdanpanah H, Nobari RF ,Hashemipour M, Maracy M, Moafi M. Spatial analysis of Neonatal Congenital Hypothyroidism and Nitrate as an environmental pollutant in Isfahan Province during 2010-2013. Int J Prev Med 2015;6:1-6.

24. Bastida AZ, Hernández Tellez M, Montes LB, Torres IM, Paniagua JJ, Martínez GM. Spatial and temporal distribution of tuberculosis in the State of Mexico, Mexico. Sci World J 2012; 2012:1-7.

25. Daliri S, Asadollahi K, Rahimi N, Sayehmiri K. Incidence of glucose-6-phosphate dehydrogenase deficiency in malariaprone regions of Fars province. Tehran Uni Med J 2017;75:669-74.

26. Ashtari F, Karimi A, Delpisheh A, Meamar R, Sayehmiri K, Daliri S. Estimated incidence rate of multiple sclerosis and its relationship with geographical factors in Isfahan province between the years 2001 and 2014. Int J Prev Med 2018;9:1-5.

27. Karimi A, Delpisheh A, Ashtari F, Sayehmiri K, Meamar R. The Relationship between the Amount of Radiation, Relative Humidity, and Temperature ith the Risk of Multiple Sclerosis in Isfahan Province, Iran, during the Years 2001-2014. J Isfahan Med Sch 2017;35:434-9.

28. Siami R, Kosarian M, Valaei N, Hatami H, Mirzajani M. Neonatal screening for congenital hypothyroidism and increase transient TSH, Mazandaran, 2006-2010. Res Med 2014;37:244-52.

29. Beheshti Z, Rezaei R, Alipour A, Kosarian M, Saatsaz S. A 7-year study on the prevalence of congenital hypothyroidism in northern Iran. Electron Physician 2018;10:6689-96.

30. Veisani Y, Sayehmiri K, Rezaeian S, Delpisheh A. Congenital hypothyroidism screening program in Iran; a systematic review and meta analysis. Iran J Pediatr 2014;24:665-72.

31. Vandevijvere S, Coucke W, Vanderpas J, Trumpff C, Fauvart M, Meulemans A, et al. Neonatal thyroid-stimulating hormone concentrations in Belgium: A useful indicator for detecting mild iodine deficiency?. PLoS One 2012;7:e47770.

32. Delshad H. History of the iodine deficiency in the world and Iran. IJEM 2008; 9: 439-53. [In Persian] 